\title{
Enalapril in the treatment of hypertension with renal artery stenosis
}

\author{
G P HODSMAN, J J BROWN, A M M CUMMING, D L DAVIES, B W EAST, A F LEVER, \\ J J MORTON, G D MURRAY, I ROBERTSON, J I S ROBERTSON
}

\begin{abstract}
The converting enzyme inhibitor enalapril, in single daily doses of $10-40 \mathrm{mg}$, was given to 20 hypertensive patients with renal artery stenosis. The blood pressure fall six hours after the first dose of enalapril was significantly related to the pretreatment plasma concentrations of active renin and angiotensin II and to the concurrent fall in angiotensin II. Blood pressure fell further with continued treatment; the long term fall was not significantly related to pretreatment plasma renin or angiotensin II concentrations. At three months, 24 hours after the last dose of enalapril, blood pressure, plasma angiotensin II, and converting enzyme activity remained low and active renin and angiotensin I high; six hours after dosing, angiotensin II had, however, fallen further. The rise in active renin during long term treatment was proportionally greater than the rise in
\end{abstract}

Medical Research Council Blood Pressure Unit, Western Infirmary, Glasgow G11 6NT

G P HODSMAN, MRCP, medical registrar

J J BROWN, FRSE, FRCP, consultant physician

A M M CUMMING, RGN, clinical nursing officer

A F LEVER, FRSE, FRCP, consultant physician

J J MORTON, PHD, scientist

J I S ROBERTSON, FRSE, FRCP, consultant physician

University Department of Medicine, Western Infirmary, Glasgow G11 6NT

D L DAVIES, FRCP, consultant physician

Department of Statistics, The University, Glasgow

G D MURRAY, PHD, lecturer in statistics

Scottish Universities' Research and Reactor Centre, East Kilbride, Glasgow

B W EAST, PHD, physicist

I ROBERTSON, PHD, physicist

Correspondence to: Dr J I S Robertson. angiotensin I; this probably reflects the fall in renin substrate that occurs with converting enzyme inhibition. Enalapril alone caused reduction in exchangeable sodium, with distinct increases in serum potassium, creatinine, and urea. Enalapril was well tolerated and controlled hypertension effectively long term; only two of the 20 patients required concomitant diuretic treatment.

\section{Introduction}

We have reported previously ${ }^{2}$ the use of the orally active converting enzyme inhibitor captopril in the preoperative treatment of hypertension associated with unilateral renal artery stenosis. Long term treatment with captopril effectively controlled hypertension in most of these patients. Moreover, it promised well as a predictor of blood pressure response to operation, and this latter aspect has since been confirmed. We have also reported that oral captopril in a dose of $150 \mathrm{mg}$ three times daily achieves sustained suppression of peripheral plasma angiotensin II concentration throughout 24 hours ${ }^{4}$; however, the efficacy in this respect of the lower doses of captopril currently recommended ${ }^{5}$ has yet to be established.

We present here data on the use of long term oral enalapril, a newer converting enzyme inhibitor, in a single daily dose in 20 patients with hypertension and renal artery stenosis. We published earlier a preliminary report on this agent in a smaller number of patients. ${ }^{6}$

\section{Patients and methods}

All patients gave informed consent to the study, which was approved by the hospital's ethical supervisory committee. Two study protocols were followed. Group 1 consisted of 10 patients with unilateral renal artery stenosis and good overall renal function. Previous antihypertensive treatment was withdrawn to permit detailed measurement of blood pressure, serum and body electrolyte content, and components of the renin angiotensin system during the administration of placebo and then during long term enalapril treatment. Group 2 comprised 10 patients with unilateral or bilateral renal artery disease in whom 
severe or resistant hypertension necessitated the continuation of previous antihypertensive treatment up to the time that enalapril was given.

\section{GROUP 1}

These 10 patients (aged 37-56 years; two women) all had unilateral renal artery stenosis or occlusion on renal arteriography; nine had radiological evidence of atheromatous stenosis and one of fibromuscular hyperplasia. The diagnosis was supported by the results of isotope renography ${ }^{7}$ in all patients. Bilateral renal vein renin measurements ${ }^{8}$ gave higher values on the affected side in nine patients; this test was not done in one man with unilateral renal artery occlusion. Seven also had divided ureteric catheter studies performed ${ }^{9}$ with confirmation of the diagnosis; this was not done in one patient who had renal artery occlusion on arteriography, and in two other patients the procedure was technically unsatisfactory. Thus in all patients the diagnosis was based on arteriography and renography plus the results of at least one other test. Every patient had normal serum electrolyte values and satisfactory overall renal function (mean serum creatinine $103(\mathrm{SEM} 8) \mu \mathrm{mol} / 1(1.2(0.09) \mathrm{mg} / 100 \mathrm{ml}))$. Seven of the 10 patients had previously poor blood pressure control while taking a combination of beta blocker and diuretic, together with either hydralazine (three patients), prazosin (one patient), minoxidil (one patient), or methyldopa (one patient). One patient had received diuretic alone with poor response, and two patients had received no previous antihypertensive treatment. Three patients had proteinuria of $0.3-1 \cdot 3 \mathrm{~g} / 24$ hours. Mean outpatient blood pressure on previous treatment was 183/109 (SEM 10/3) $\mathrm{mm} \mathrm{Hg}$.

All treatment was stopped at least 14 days before enalapril was started except in one patient who received prazosin alone ${ }^{10}$ until two days before enalapril was given. The patients were admitted and ate a normal ward diet; previous studies have shown that plasma renin, angiotensin II, and aldosterone values are in these circumstances similar to those obtained during strictly controlled sodium and potassium intake. ${ }^{11}$ Matching placebo was given at 1000 each morning for five days before active drug was administered; thereafter enalapril was given at 1000 each morning. Two patients received placebo for only two days before enalapril was given because of greatly increased blood pressure.

The patients were started on $10 \mathrm{mg}$ enalapril daily, which was continued for each of the six days of their stay in hospital. After discharge in all 10 the enalapril dose was adjusted until supine and erect blood pressures were below $140 \mathrm{~mm} \mathrm{Hg}$ systolic and $90 \mathrm{~mm} \mathrm{Hg}$ diastolic (phase V) four hours after the morning dose, or until a maximum dose of $40 \mathrm{mg}$ daily had been reached. No drug other than enalapril was given in this study. After three months' treatment with enalapril the patients were readmitted and again studied in circumstances identical to those at the start of treatment. At three months six were receiving $10 \mathrm{mg}$, one $20 \mathrm{mg}$, and three $40 \mathrm{mg}$ enalapril daily.

\section{GROUP 2}

These 10 patients (aged 15-61 years; five women) were more seriously ill and therefore unsuitable for study according to the above protocol. On arteriography five had unilateral renal artery stenosis or occlusion and five had bilateral renal artery disease. Eight had very high blood pressure (four were in the malignant phase with bilateral retinal haemorrhages, exudates, and papilloedema). One had cardiac failure and recent hypertensive encephalopathy. Three had overall renal impairment (mean SEM) serum creatinine for the whole group was $132(17) \mu \mathrm{mol} / 1(1.5(0.2) \mathrm{mg} / 100 \mathrm{ml}))$. Four had proteinuria of $0 \cdot 7-4 \cdot 2 \mathrm{~g} / 24$ hours. Existing treatment in the patients of group 2 included various combinations of diuretics, beta blocking agents, prazosin, hydralazine, and nifedipine. All were studied as inpatients initially and were readmitted for reassessment three months later. Supine blood pressure immediately before enalapril was introduced was 190/104 (SEM 15/5) $\mathrm{mm} \mathrm{Hg}$. Enalapril was given in a starting dose of $10 \mathrm{mg}$ and increased to a maximum of $40 \mathrm{mg}$ daily with lower dosage in those with renal impairment. Over a period of 12 weeks treatment was adjusted and other drugs were withdrawn whenever possible.

Peripheral venous blood was taken for measurement of plasma active renin concentration ${ }^{8}$ (normal range $10-50 \mathrm{mU} / \mathrm{l}$ ), blood angiotensin $\mathrm{I}^{12}$ (normal range $3-15 \mathrm{pmol} / \mathrm{l}$ ), plasma aldosterone ${ }^{13}$ (normal range $<500 \mathrm{pmol} / 1(180 \mathrm{ng} / \mathrm{l})$ ), plasma converting enzyme activity, ${ }^{14}$ and plasma angiotensin $\mathrm{II}^{15}$ (normal range $5-35 \mathrm{pmol} / 1$ after 30 minutes of recumbency before the first dose of enalapril and six and 24 hours later. Supine and erect pulse rate and blood pressure (after two minutes' standing) were recorded after blood sampling by the same observer (GPH). The Hawksley random zero sphygmomanometer ${ }^{16}$ was used and phase $\mathrm{V}$ was taken as diastolic. These measurements were repeated under identical conditions after six days (group 1 patients only) and after 12 weeks of treatment. Measurements were made of exchangeable sodium ${ }^{17}$ and total body potassium ${ }^{18}$ in the patients of group 1 before and during long term enalapril treatment.

The statistical comparisons are based on paired $t$ tests with all biochemical measurements transformed to a logarithmic scale. The correlation coefficients quoted are product moment correlations, with biochemical measurements also analysed on a logarithmic scale. The mean arterial pressure (diastolic plus one third pulse pressure) was calculated for correlations involving blood pressure.

\section{Results}

GROUP 1

Figure 1 compares blood pressure and various biochemical measurements six hours after the daily dose of enalapril on the first and sixth days of treatment, and at three months, with those on the final day of placebo at the comparable time after dosing.

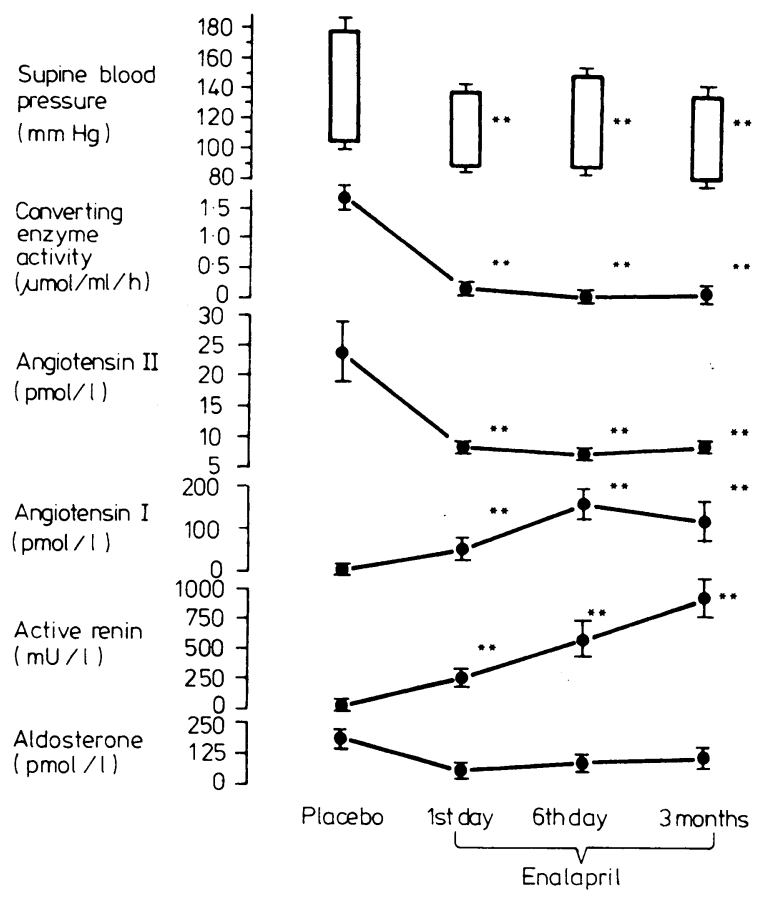

FIG 1-Group 1. Measurements made six hours after dosing on the final day of placebo, on the first day of enalapril treatment, on the sixth day of enalapril treatment, and at the third month of enalapril treatment. Statistical comparisons with placebo values: ${ }^{* *} \mathrm{p}<0.01$

Six hours after the initial dose of enalapril, noticeable falls in plasma converting enzyme activity and in angiotensin II had occurred, with converse increases in blood concentrations of angiotensin I and in plasma active renin concentration. The small fall in mean plasma aldosterone concentration was not significant. A highly significant reduction in blood pressure accompanied the fall in plasma angiotensin II, and these changes were significantly correlated $(\mathrm{r}=0.67 ; \mathrm{p}<0.05)$; the blood pressure fall at six hours also correlated with the plasma concentrations of active renin $(r=0.76 ; p<0.05)$ and angiotensin II $(r=0.70 ; p<0.05)$ before enalapril treatment.

With continued enalapril treatment, suppression of plasma converting enzyme activity and angiotensin II similar to that on the first day was seen at six days and at three months six hours after dosing. Active renin concentration increased progressively from the first to the sixth day and from the sixth day to the third month of treatment. While mean blood concentration of angiotensin I also rose further from the first to the sixth day of enalapril treatment there was there- 
after no further rise. The slight fall in mean plasma aldosterone remained insignificant. Blood pressure remained controlled at six days and three months. During long term treatment, however, the blood pressure fall was less closely related than on the first day either to the pretreatment plasma renin or angiotensin II concentrations or to the long term fall in plasma angiotensin II (respective correlation coefficients $0.44,0.42$, and 0.56 ; none significant).

Figure 2 compares measurements made on the last day of placebo with those at the third month of enalapril treatment, 24 hours after the preceding dose and again six hours after the morning dose of drug.

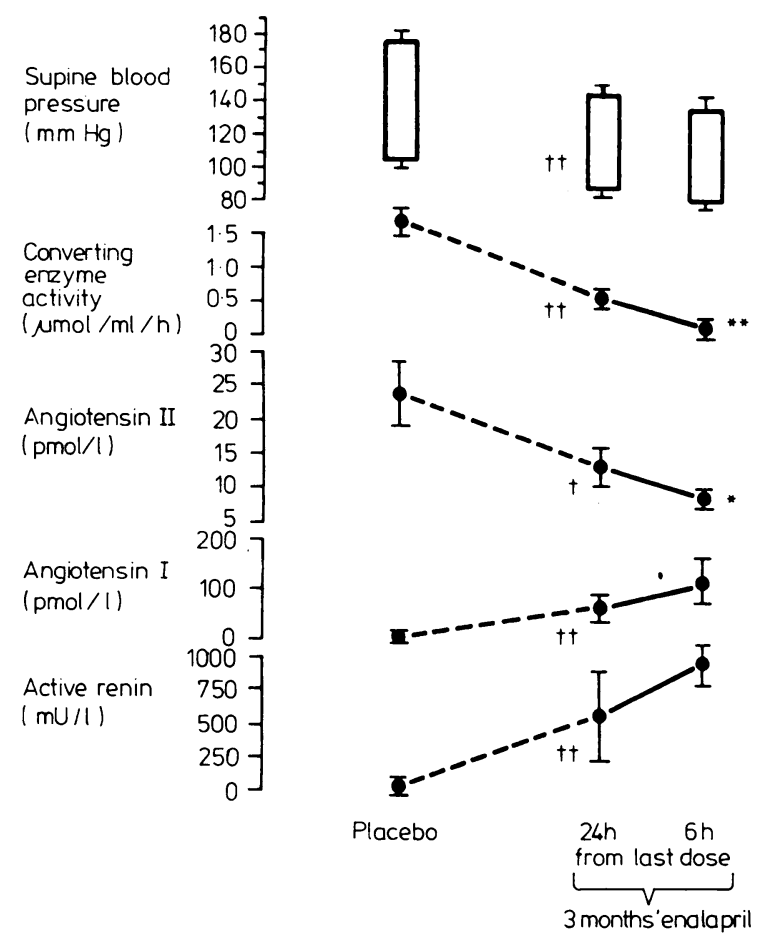

FIG 2-Group 1. Comparison of values after three months of continuous enalapril treatment alone with final day of placebo. Measurements on enalapril treatment shown 24 hours and six hours from the preceding dose. Daggers show comparisons with placebo values: $\dagger p<0.05, \dagger \dagger p<0.01$. Asterisks show comparisons with 24 hour values: ${ }^{*} p<0.05,{ }^{* *} p<0.01$

A continued effect of enalapril was evident 24 hours after the last dose of the drug, with a noticeable rise in active renin and angiotensin I and reduction of converting enzyme activity and angiotensin II. Blood pressure also remained significantly reduced 24 hours after dosing compared with pretreatment values.

Nevertheless, after the morning dose of enalapril at the third month significant further falls in plasma converting enzyme activity and angiotensin II accurred, while mean values for active renin and angiotensin $I$ increased. The small additional lowering of arterial pressure six hours after dosing was not statistically significant.

Figure 3 shows systolic and diastolic blood pressures and heart rates, lying and standing, on placebo and at the sixth day and third month of enalapril treatment. Values are means of measurements made two, six, and 24 hours after dosing. A significant fall in blood pressure had occurred by the sixth day of enalapril treatment, and there was a further highly significant fall by three months without a marked postural component or change in mean heart rate. Good blood pressure control was maintained after discharge from the ward at three months (seated clinic values $142 / 82(6 / 3) \mathrm{mm} \mathrm{Hg}$ four hours after dosing).

There was a significant rise in serum creatinine during long term enalapril treatment; serum urea also increased (table). The rise in serum creatinine was related to the fall in mean arterial pressure $(r=-0.68 ; p<0.05)$. Serum potassium rose significantly, but in no individual was this pronounced. There was no change in serum sodium. Proteinuria cleared in two and was reduced in the third patient in whom it had previously been present.

There were no measurable long term changes in total body potassium. Total exchangeable sodium, however, was lowered during treatment in nine patients and unchanged in the 10th, falling from a mean of $101 \%$ to $96 \%$ of predicted normal values. The mean reduction was $140 \mathrm{mmol}(\mathrm{mEq})$ and was highly significant $(\mathrm{p}<0.001)$. The fall in exchangeable sodium was not significantly related to the rise in serum creatinine.

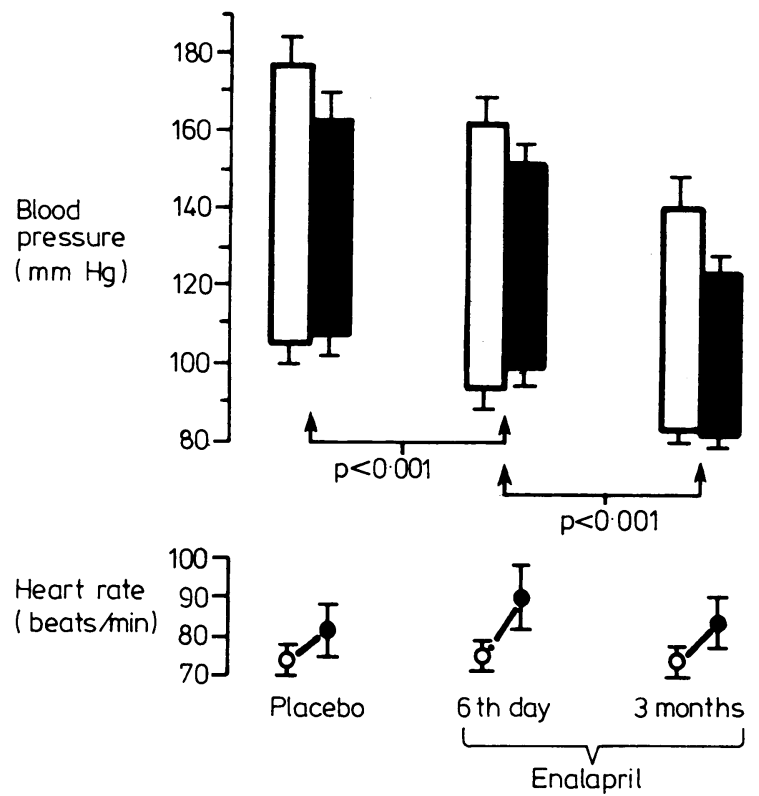

FIG 3-Group 1. Comparison of supine (open column) and erect (solid column) blood pressures and pulse rate before and during enalapril treatment. Means (SEM) of measurements made two, six, and 24 hours after dosing.

Serum sodium, potassium, creatinine, and urea in patients of group 1 on the final day of placebo, on the sixth day of enalapril, and after three months of enalapril treatment alone. Results are means (SEM)

\begin{tabular}{lccc}
\hline \multirow{2}{*}{ Serum } & \multirow{2}{*}{ Placebo } & \multicolumn{2}{c}{ Enalapril } \\
\cline { 3 - 4 } & & 6 days & 3 months \\
\hline Sodium $(\mathrm{mmol} / \mathrm{l})$ & $140 \cdot 8(0 \cdot 7)$ & $140 \cdot 6(0 \cdot 5)$ & $140 \cdot 4(0 \cdot 7)$ \\
Potassium $(\mathrm{mmol} / \mathrm{l})$ & $3 \cdot 8(0 \cdot 10)$ & $4 \cdot 0(0 \cdot 08)$ & $4 \cdot 3(0 \cdot 07)^{* *}$ \\
Creatinine $(\mu \mathrm{mol} / \mathrm{l})$ & $103(8)$ & $117(9)$ & $127(10)^{* * *}$ \\
Urea $(\mathrm{mmol} / 1)$ & $5 \cdot 1(0 \cdot 4)$ & $5 \cdot 2(0 \cdot 4)$ & $6 \cdot 2(0 \cdot 5)^{*}$ \\
\hline
\end{tabular}

${ }^{*} \mathrm{p}<0.05 . \quad * * \mathrm{p}<0.01 . \quad * * * \mathrm{p}<0.001$

Conversion: SI to traditional units-Sodium: $1 \mathrm{mmol} / 1 \approx 1 \mathrm{mEq} / \mathrm{l}$. Potassium: $6.02 \mathrm{mg} / 100 \mathrm{ml}$.

GROUP 2

Supine and erect blood pressures on previous antihypertensive treatment and immediately before enalapril was given were 190/104 $(15 / 5) \mathrm{mm} \mathrm{Hg}$ and $179 / 108(11 / 4) \mathrm{mm} \mathrm{Hg}$ respectively. After three months four patients were receiving $10 \mathrm{mg}$, three patients $20 \mathrm{mg}$, and three patients $40 \mathrm{mg}$ enalapril daily. The blood pressures of seven patients were well controlled by enalapril alone. Three required additional treatment. One patient with overall renal impairment continued also on frusemide $500 \mathrm{mg}$ daily, together with atenolol $50 \mathrm{mg}$ daily for control of symptomatic tachycardia. One patient remained on chlorthalidone $25 \mathrm{mg}$ daily, and also atenolol $100 \mathrm{mg}$ daily because of angina. One patient needed atenolol alone, $50 \mathrm{mg}$ daily, for control of symptomatic tachycardia.

In this group of 10 patients, after three months of enalapril supine and erect blood pressures had fallen to $142 / 84(5 / 8) \mathrm{mm} \mathrm{Hg}$ and $129 / 85(7 / 5) \mathrm{mm} \mathrm{Hg}(\mathrm{p}<0.01)$ respectively. Corresponding seated measurements in the outpatient clinic were $150 / 87$ (5/3) $\mathrm{mm} \mathrm{Hg}$ four hours after dosing. There were no changes in mean serum sodium or potassium and no deterioration in mean or individual overall renal function (serum creatinine $132(17) \mu \mathrm{mol} / \mathrm{l}(1.49(0 \cdot 19)$ $\mathrm{mg} / 100 \mathrm{ml})$ on previous treatment, $133(23) \mu \mathrm{mol} / 1(1.5(0.26) \mathrm{mg} /$ $100 \mathrm{ml}$ ) after four months of enalapril). Previous proteinuria cleared in two patients and was distinctly less in the other two. 


\section{SIDE EFFECTS}

The drug was well tolerated by all 20 patients and problems were minor. One man recovered previously impaired sexual function. Four patients (one also on a large dose of loop diuretic) developed symptomatic tachycardia in the supine and standing positions; in two patients the tachycardia slowly and spontaneously resolved without additional treatment, but two patients, both in group 2, required the addition of a beta blocker.

One patient taking only enalapril developed de novo Raynaud's phenomenon. In another woman, also on enalapril alone, pre-existing Raynaud's phenomenon distinctly worsened.

One patient in group 1 with a small, poorly functioning kidney developed complete occlusion of a previously tightly stenosed renal artery during enalapril treatment though he remained asymptomatic with good blood pressure control throughout. His overall renal function did not deteriorate seriously, the rise in serum creatinine over three months, from 118 to $127 \mu \mathrm{mol} / 1(1.33$ to $1.44 \mathrm{mg} / 100 \mathrm{ml})$, being less than the average for the whole of group 1 .

There were no instances of drug induced proteinuria; indeed, significant proteinuria in seven subjects before starting enalapril was greatly reduced in three and resolved completely in four.

There were no examples of taste disturbance, rash, glycosuria, or haematological disorder.

\section{Discussion}

The present study has shown that enalapril in the range $10-40 \mathrm{mg}$ daily produces distinct falls in plasma converting enzyme activity and in angiotensin II, which are greater at six hours than at 24 hours after dosing and are sustained during continued treatment. Plasma active renin concentration and blood angiotensin I increase, but there is no evidence of the converting enzyme inhibition being overcome during prolonged treatment. The proportionally greater rise in active renin concentrations than in angiotensin I between the sixth day and the third month of treatment (fig 1) probably reflects the fall in renin substrate that occurs with converting enzyme inhibition. ${ }^{19}$ Mean plasma aldosterone was not high before treatment, and the reduction after enalapril treatment was not statistically significant.

In none of the 10 patients of group 1 were pretreatment plasma renin or angiotensin II concentrations particularly high. Thus while the fall in arterial pressure six hours after the first dose of enalapril was (as previously found with captopril ${ }^{12}$ ) proportional to the concurrent fall in plasma angiotensin II, in no patient was there profound hypotension. ${ }^{20}$

Highly significant reductions in arterial pressure without marked postural effects were seen on the sixth day of treatment. At three months, although mean plasma angiotensin II concentration was no different from that at six days, a further highly significant fall in blood pressure had taken place; we have discussed possible mechanisms in this slow fall in pressure elsewhere. ${ }^{21-23}$ Despite the distinct but minor variations in angiotensin II over 24 hours, blood pressure control remained good throughout the day. Blood pressure reduction by enalapril was similarly impressive in the more severely hypertensive patients with more complicated conditions of group 2, and additional treatment was largely unnecessary.

The striking and consistent reduction in exchangeable sodium effected by long term enalapril contrasts with the results of our earlier study of captopril in renovascular hypertension, in which, however, were included patients with the hyponatraemic syndrome and severe sodium depletion. ${ }^{12}$ In this present study the sodium loss occurred despite the fall in arterial pressure and hence diminution of pressure natriuresis. The fall in plasma aldosterone concentration seems too minor and inconsistent to provide a full explanation. Perhaps more plausible is the elimination by converting enzyme inhibition of direct actions of angiotensin II on the kidneys. ${ }^{12} 2124$

A slight but significant increase in serum potassium concentration is known to occur with converting enzyme inhibition. In the present series it probably resulted in part from loss of sodium in the absence of a rise in aldosterone concentration.
The consistent increases in serum creatinine and urea concentrations in group 1 were not correlated with the fall in exchangeable sodium but were correlated with the reduction in arterial pressure. There are several reports of worsening of renal function with converting enzyme inhibition, particularly in patients with bilateral renal artery stenosis or with stenosis of the artery to a sole remaining kidney ${ }^{25-27}$; diuretics have been given also in many of these studies. We did not observe serious renal impairment in the present series although diuretics were not used concurrently in any of our five patients with bilateral renal artery lesions. One patient in group 1 suffered occlusion of an already severely narrowed renal artery during enalapril treatment, although his overall renal function did not change appreciably. Many such patients progress to renal artery occlusion irrespective of treatment, and possibly a reduction in blood pressure can heighten this risk. Moreover, converting enzyme inhibitors may be especially likely to cause this complication. ${ }^{28} 29$ The occurrence has been said not to be unduly frequent, however, at least with captopril. ${ }^{30}$

Only one patient of the present 20 has subsequently had surgical treatment of renal artery stenosis; we thus cannot be certain that the renal artery lesions were responsible for the hypertension in most of the patients in this series, though the diagnosis was supported by tests additional to renal arteriography.

Side effects were trivial, and this was an important factor in limiting enthusiasm of the patients for surgical intervention.

Enalapril appears to be an effective and well tolerated agent given as the only drug once daily in patients with hypertension and associated renovascular disease.

We are grateful to Merck, Sharp and Dohme for financial support for these studies.

\section{References}

${ }^{1}$ Atkinson AB, Brown JJ, Cumming AMM, et al. Captopril in renovascular hypertension: long-term use in predicting surgical outcome. $\mathrm{Br} \mathrm{Med} \mathcal{F}$ $1982 ; 284: 689-93$

2 Atkinson AB, Brown JJ, Cumming AMM, et al. Captopril in the management of hypertension with renal artery stenosis: its long-term effect as a predictor of surgical outcome. Am f Cardiol 1982;49:1460-6.

${ }^{3}$ Staessen J, Bulpitt C, Fagard R, Lijnen P, Amery A. Long-term converting-enzyme inhibition as a guide to surgical curability of hypertension associated with renovascular disease. Am f Cardiol 1983;51: 1317-22.

${ }^{4}$ Atkinson $\mathrm{AB}$, Cumming $\mathrm{AMM}$, Brown JJ, et al. Captopril treatment: inter-dose variations in renin, angiotensins $I$ and $I I$, aldosterone and blood pressure. Br f Clin Pharmacol 1983;13:855-8.

${ }^{5}$ Hodsman GP, Robertson JIS. Captopril: five years on. Br Med $\mathcal{F} 1983$; $287: 851-2$.

6 Hodsman GP, Brown JJ, Davies DL, et al. Converting-enzyme inhibitor enalapril (MK421) in treatment of hypertension with renal artery stenosis. Br Med F 1982;285:1697-9.

${ }^{7}$ Mackay A, Eadie AS, Cumming AMM, Graham AG, Adams FG, Horton PW. Assessment of total and divided renal plasma flow by 123I-hippuran renography. Kidney International 1981;19:49-57.

${ }^{8}$ Millar JA, Leckie BJ, Semple PF, Morton JJ, Sonkodi S, Robertson JIS. Active and inactive renin in human plasma: renal arteriovenous differences and relationships with angiotensin and renin substrate. Circ Res 1978;43 (suppl 1):120-7.

${ }^{9}$ Brown JJ, Lever AF, Robertson JIS. Renal hypertension: diagnosis and treatment. In: Black D, Jones NF, eds. Renal disease, 4th ed. Oxford: Blackwell, 1979:731-65.

${ }^{10}$ McAreavey D, Cumming AMM, Sood VP, et al. The effect of oral prazosin on blood pressure and plasma concentrations of renin and angiotensin II in man. Clin Sci 1981;61 (suppl 7):457-60.

11 Agabiti-Rosei E, Brown JJ, Cumming AMM, et al. Is the "sodium index" a useful way of expressing clinical plasma renin, angiotensin and aldosterone values? Clin Endocrinol 1978;8:141-7.

12 Waite MA. Measurement of concentrations of angiotensin I in human blood by radioimmunoassay. Clin Sci Mol Med 1973;45:51-64.

13 Fraser R, Guest S, Young J. Comparison of double isotope derivative and radioimmunological estimation of plasma aldosterone concentration. Clin Sci Mol Med 1973;45:411-5.

14 Cushman DW, Cheung HS. Spectrophotometric assay and properties of the angiotensin-converting enzyme of rabbit lung. Biochem Pharmaco $1971 ; 20: 1637$

${ }^{15}$ Atkinson AB, Morton JJ, Brown JJ, et al. Captopril in clinical hypertension Changes in components of the renin-angiotensin system and in body 
composition in relation to fall in blood pressure with a note on measurement of angiotensin II during converting enzyme inhibition. Br Heart $\mathcal{F}$ $1980 ; 44: 290-6$.

16 Wright BM, Dore CF. A random-zero sphygmomanometer. Lancet $1970 ; 1: 337-8$

${ }^{17}$ Davies DL, Robertson JWK. Simultaneous measurements of total exchangeable potassium and sodium using ${ }^{43} \mathrm{~K}$ and ${ }^{24} \mathrm{Na}$. Metabolism 1973;22:133-7.

18 Boddy K, King PC, Tothill P, Strong JA. Measurement of total body potassium with a shadow shield whole-body counter: calibration and errors. Phys Med Biol 1971;16:275-82.

19 Rasmussen S, Nielsen MD, Giese J. Captopril combined with thiazide lowers renin substrate concentration: implications for methodology in renin assays. Clin $S_{c i} 1981 ; 60: 591-3$.

${ }^{20}$ Hodsman GP, Isles CG, Murray GD, Usherwood TP, Webb DJ, Robertson JIS. Factors related to first dose hypotensive effect of captopril: prediction and treatment. $\mathrm{Br}$ Med f 1983;286:832-4.

${ }^{21}$ Brown JJ, Casals-Stenzel J, Cumming AMM, et al. Angiotensin II, aldosterone and arterial pressure: a quantitative approach. Hypertension 1979;1:159-79.

22 Bean BL, Brown JJ, Casals-Stenzel J, et al. The relation of arterial pressure and plasma angiotensin II in the conscious dog. A change produced by prolonged infusion of angiotensin II. Circ Res 1979;44: 452-8.

${ }^{23}$ Atkinson AB, Brown JJ, Fraser R, et al. Antagonists and inhibitors of the renin-angiotensin-aldosterone system in the treatment of hyper- tension. In: Robertson JIS, Pickering Sir George, eds. The therapeutics of hypertension. London: Academic Press, 1980:29-61. (Royal Society of Medicine International Congress \& Symposium Series No 26.)

${ }^{24}$ Hollenberg NK. Renal response to angiotensin-converting enzyme inhibition. Am 7 Cardiol 1982;49:1425-9.

${ }^{25}$ Farrow PR, Wilkinson R. Reversible renal failure during treatment with captopril. $\mathrm{Br} \mathrm{Med} \mathcal{F} 1979 ; \mathrm{i}: 1680$.

26 Hrick De, Browning PJ, Kopelman R, Goorno WE, Madias NE, Dzau VJ. Captopril induced functional renal insufficiency in patients with bilateral renal-artery stenoses or renal artery stenosis in a solitary kidney. $N$ Engl F Med 1983;308:373-6.

${ }^{27}$ Silas JH, Klenka Z, Solomon SA, Bone JM. Captopril induced reversible renal failure: a marker of renal artery stenosis affecting a solitary kidney. Br Med F 1983; : 1702-3.

28 Anderson WP, Korner PI, Johnston CI. Acute angiotensin II mediated restoration of distal renal artery pressure in renal artery stenosis and its relationship to the development of sustained "one-kidney" hypertension in conscious dogs. Hypertension 1979;1:292-8.

29 Aldigier J-C, Plouin P-F, Guyene TT, Thibonnier M, Corvol P, Menard J. Comparison of hormonal and renal effects of captopril in severe essential and renovascular hypertension. Am $\mathcal{F}$ Cardiol 1982;49:1447-52.

${ }^{30}$ Hollenberg $N$. Renal artery thrombosis caused by antihypertensive treatment. Br Med f 1983;286:893.

(Accepted 22 August 1983)

\title{
Psychiatric morbidity in patients with alcoholic liver disease
}

\author{
ISAAC EWUSI-MENSAH, J B SAUNDERS, A D WODAK, R M MURRAY, ROGER WILLIAMS
}

\begin{abstract}
Seventy one patients with alcoholic liver disease and an equal number with non-alcoholic liver disease were interviewed using the schedule for affective disorders and schizophrenia. Forty seven $(66 \%)$ of the group with alcoholic liver disease had or had had psychiatric illnesses compared with $23(32 \%)$ of the control group (p<0.001). Affective disorder, particularly major depression, neurotic disorders, and antisocial personality, were all more common among the patients with alcoholic liver disease than the controls. No patient had schizophrenia or other forms of psychosis. Among the patients with alcoholic liver disease 11 men (24\%) and 14 women $(54 \%)$ had an affective or a neurotic disorder that had antedated their heavy drinking, and $30(77 \%)$ of those who had had such a problem at any time had symptoms at the time of interview.

Abstinence from alcohol is essential for patients with severe alcoholic liver disease. In view of the high prevalence of psychiatric disorders in these patients psychiatric assessment is important to increase the patients' likelihood of complying with such advice.
\end{abstract}

\footnotetext{
Liver Unit, King's College Hospital and Medical School, and Institute of Psychiatry, London SE5

ISAAC EWUSI-MENSAH, MRCPSYCH, honorary senior registrar

J B SAUNDERS, MRCP, lecturer

A D WODAK, FRACP, honorary senior registrar

R M MURRAY, MD, MRCPSYCH, dean, Institute of Psychiatry

ROGER WILLIAMS, MD, FRCP, consultant physician and director of liver unit

Correspondence to: Dr J B Saunders.
}

\section{Introduction}

Although individual susceptibility to the hepatotoxic effects of alcohol varies greatly, both alcoholic hepatitis and alcoholic cirrhosis usually take many years to develop. ${ }^{12}$ The average cumulative alcohol intake reported by patients in a recent study was nearly $800 \mathrm{~kg}$, an amount equivalent to $120 \mathrm{~g}$ alcohol (eight pints of beer or half a bottle of spirits) daily for 20 years. ${ }^{3}$ Many factors contribute to the development and perpetuation of excessive drinking, including social and cultural influences, family background, personality, and psychiatric disturbance. The association between alcoholism and psychiatric morbidity is well established, ${ }^{4-7}$ and in many cases alcohol abuse seems to be symptomatic of an underlying psychiatric illness.

Most studies linking alcoholism and psychiatric illness have been conducted among patients presenting to psychiatric units for treatment of alcohol dependence and the attendant social and psychological problems. The prevalence of psychiatric illness in patients presenting with physical complications of excessive drinking has not been systematically investigated. The impression has been that overt psychiatric disorder is uncommon, and in a recent study of 100 patients with alcoholic liver disease only nine were thought to require psychiatric help. ${ }^{8}$ This relative rarity of psychiatric illness accords with suggestions that many patients who develop alcoholic liver disease are only heavy "social" drinkers, and in a recent study severe alcohol dependence was found to be uncommon."

The aim of the present study was to assess the prevalence and clinical nature of psychiatric morbidity in patients presenting for management of alcoholic liver disease. We also studied a group of patients with non-alcoholic liver disease who were similar with respect to age, sex, social class, and severity of disease.

\section{Patients and methods}

Over 18 months we interviewed 142 patients within a week after admission to hospital. Seventy one (45 men and 26 women) had 